\title{
Keberlanjutan Finansial Usaha Beras Siger: Studi Kasus pada UMK peserta Model Pengembangan Pangan Pokok Lokal (MP3L) di Propinsi Lampung
}

\section{Beras Siger Business Financial Sustainability: Case Study at UMK participants in the Local Food Development Model (MP3L) in Lampung Province}

\author{
Fitriani $^{\left.{ }^{* *}\right)}$, Sutarni ${ }^{1)}$, Teguh Budi Trisnanto ${ }^{1)}$, Cholid Fatih ${ }^{1)}$, Robet Asnawi ${ }^{2)}$ \\ 1)Agribisnis Pangan Politeknik Negeri Lampung \\ ${ }^{2)}$ Balai Pengkajian Teknologi Pertanian (BPTP) Lampung \\ Email : fitriani@polinela@ac.id
}

\begin{abstract}
The Local Staple Food Development Model (MP3L) in Lampung Province has been developed from 2013 introducing tiwul as analog rice, known as Beras. Beras Siger program introduced analog processing technology through the use of equipment modern and improved production processes, as well as packaging. This study focuses on analyzing the financial sustainability of the Beras Siger business participants. This research is a case study. Beras Siger business participants in South Lampung Region in Jati Agung District selected case study. Primary data required includes ownership of land assets, buildings and equipment, production facility/input needs, production and the selling price, sales volume, revenue and income and other general descriptions. Financial analysis is performed using Net Present Value (NPV), Benefit Cost Ratio (BCR), and Internal Rate of Return (IRR) criteria. Based on the results of the analysis it can be concluded that the cost structure of the Beras Siger program participants showed a very high value component of production equipment. The size of the investment value of program participants causes the business needs a minimum of 7 years to be able to obtain a profitable return. In the existing situation, the program participants' Beras Siger business will be financially feasible if they increase production capacity by $20 \%$.
\end{abstract}

Keywords: Beras Siger, financial, sustainability, investment, analog

Disubmit: 4 Januari 2019 Diterima: 3 Februari 2019 Disetujui: 17 Maret 2019

\section{PENDAHULUAN}

Ubi kayu, merupakan komoditas strategis dalam perekonomian Propinsi Lampung, karena merupakan salah satu komoditas pangan penting selain padi dan jagung. Propinsi Lampung merupakan sentra penghasil ubi kayu terbesar secara nasional. Kontribusi produksi ubi kayu Lampung mencapai lebih dari $30 \%$ dari produksi ubi kayu nasional. Kapasitas produksi ubi kayu 
yang sangat besar perlu diiringi dengan sistem hilirisasi pengolahan produk (agroindustri) untuk dapat memberikan multiplier efek terhadap ekonomi lokal melalui peningkatan nilai tambah, sumber pendapatan, dan lapangan usaha bagi masyarakat. Agroindustri berbasis ubi kayu berperan sentral dalam menekan kerugian akibat fluktuasi harga ubi kayu yang sangat tinggi, terlebih pada saat ketersediaannya melimpah, harga ubi kayu sangat rendah. Ketidakpastian harga menyebabkan petani ubi kayu menerima tingkat pendapatan rendah. Lebih lanjut, menyebabkan pendapatan petani masih banyak yang berada di garis kemiskinan.

Agroindustri berbasis ubi kayu skala kecil melibatkan lebih banyak tenaga kerja dan rumah tangga perdesaan. Agroindustri pangan skala UKM berperan penting dalam peningkatan pendapatan rumah tangga petani di pedesaan. Pengembangan agroindustri pangan skala UKM mendukung konsep pemerataan dan pertumbuhan ekonomi (Affandi, 2010; Elizabeth, 2010). Agroindustri berbasis ubi kayu skala kecil adalah tiwul/oyek, mocaf, klanting, opak, dan kerupuk (Indiako, dkk., 2014; Sagala, dkk., 2013; Sari, 2011; Surfiana, dkk., 2014; Yunus dan Utami, 2012; Hidayat, 2016).

Agroindustri pengolahan tiwul/oyek menjadi salah satu prioritas penting yang dikembangkan oleh Pemda Propinsi Lampung sebagai salah satu sumber pasokan substitusi beras dalam pogram diversifikasi pangan berbasis sumber daya lokal (Permentan No. 15/Permentan/OT.140/2/2013). Diversifikasi pangan dilakukan melalui penganekaragaman pangan konsumsi masyarakat untuk dapat mengurangi beras dan menganekaragamkan jenis pangan yang dikonsumsi. BKP Propinsi Lampung (2013) melaksanakan program Model Pengembangan Pangan Pokok Lokal (MP3L) mengenalkan tiwul sebagai beras analog sandingan beras. Selanjutnya, produk tersebut dikenal sebagai Beras Siger, yang merupakan singkatan dari 'singkong seger.' Program beras siger mengintroduksi teknologi pengolahan tiwul/oyek melalui penggunaan peralatan modern dan perbaikan proses produksi, juga pengemasan. Program MP3L beras siger pada awalnya dilaksanakan di Kabupaten Lampung Selatan (Desa Pancasila) dan Kota Bandar Lampung (Kecamatan Kemiling) pada tahun 2013 dan hingga saat ini dikembangkan juga di beberapa daerah sentra produksi.

Agroindustri berbasis ubi kayu, termasuk beras siger masih menghadapi tantangan dan hambatan yang kompleks, terutama pada aspek inovasi teknologi (Hidayat, 2016; Surfiana dkk., 2014; Caesarina dan Estiasih, 2016; Adicandra dan Estiasih, 2016); manajemen usaha, kelembagaan, dan pemasaran (Novia, dkk, 2013; Pahlevi, dkk., 2014; Rangkuti, dkk., 2015). Agroindustri skala rumah tangga juga menghadapi keterbatasan akses terhadap pembiayaan (Indarwanta dan Pujiastuti, 2011).

Sebagai produsen agroindustri beras siger/tiwul penting memperhitungkan tingkat keuntungan usaha untuk keberlanjutan ekonomi keluarga. Kondisi keberlanjutan keuangan usaha/finansial agroindustri beras siger/tiwul peserta program MP3L menjadi penting untuk ditelusuri. Informasi ini penting untuk memastikan keberhasilan program diversifikasi pangan berbasis sumberdaya lokal dan ketahanan pangan hingga ke level individu rumahtangga. Penelitian ini fokus pada analisis keberlanjutan finansial usaha agroindustri beras siger peserta progam.

\section{METODE PENELITIAN}

Penelitian ini dilakukan di daerah sentra produksi beras siger penerima program di Lampung Selatan di Kecamatan Jati Agung di Desa Margomulyo. Penentuan pelaku agroindustri peserta menggunakan metode studi kasus. Studi kasus memusatkan diri secara intensif pada satu obyek tertentu dan mempelajarinya sebagai suatu kasus. Studi kasus dilakukan pada UKM beras siger pelaksana program Studi kasus yang baik harus dilakukan secara langsung dalam kehidupan 
sebenarnya dari kasus yang diselidiki. Data studi kasus dapat diperoleh tidak saja dari kasus yang diteliti, juga diperoleh dari semua pihak yang mengetahui dan mengenal kasus tersebut dengan baik. Data primer yang diperlukan meliputi kepemilikan asset lahan, bangunan dan peralatan, kebutuhan sarana produksi/input usaha agroindustri beras siger/tiwul, jumlah produksi dan harga jualnya, harga jual, volume penjualan, penerimaan dan pendapatan serta gambaran umum lainnya. Data pemasaran meliputi pelaku pasar beras siger/tiwul, harga jual, jumlah penjual, jumlah yang terdistribusi, daerah pemasaran, konsumen dll. Data sekunder meliputi luas lahan dan peruntukkannya, topografi, klimatologi, dan informasi lain yang diperlukan dari instansi terkait. Analisis keuangan/finansial dilakukan dengan kriteria Net Present Value (NPV), Benefit Cost Ratio (BCR), dan Internal Rate of Return (IRR), (Gittinger, 1986; Chutubtim, 2001; Prasmatiwi \& Suryantini, 2011; Fitriani, 2007a.b)

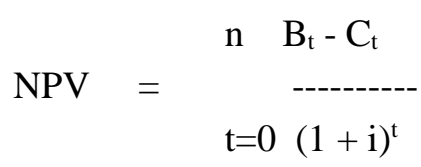

Keterangan:

$\mathrm{B}_{\mathrm{t}}=$ penerimaan (produksi $\mathrm{x}$ harga jual) pada tahun $\mathrm{t}$

$\mathrm{C}_{\mathrm{t}}=$ Biaya produksi pada tahun $\mathrm{t}$

$\mathrm{t}=$ umur ekonomis atau jumlah tahun

$\mathrm{i}=$ discount rate

Perhitungan menguntungkan akan diterima bilamana nilai NPV $>0$, semakin besar nilai NPV dari 0, maka investasi usaha tersebut dikatakan semakin menguntungkan.

$$
\begin{array}{ccc}
\sum & \multicolumn{1}{c}{\mathrm{B}_{\mathrm{t}}-\mathrm{C}_{\mathrm{t}}} \\
\mathrm{BCR}= & \begin{array}{c}
\mathrm{t}=0 \\
\mathrm{n} \quad(1+\mathrm{i})^{\mathrm{t}}
\end{array} \\
\sum_{\mathrm{t}=0}^{\mathrm{n}} \quad \mathrm{B}_{\mathrm{t}}-\mathrm{C}_{\mathrm{t}} & (1+\mathrm{i})^{\mathrm{t}}
\end{array}
$$

Keterangan:

$\mathrm{B}_{\mathrm{t}}=$ Penerimaan (produksi $\mathrm{x}$ harga jual) pada tahun $\mathrm{t}$

$\mathrm{C}_{\mathrm{t}}=$ Biaya produksi pada tahun $\mathrm{t}$

$\mathrm{t}=$ umur ekonomis atau jumlah tahun

$\mathrm{i}=$ discount rate

Investasi usaha akan menguntungkan, jika nilai BCR $>1$, dan jika $\mathrm{BCR}<1$, maka proyek akan ditolak karena tidak dapat memberi manfaat atau keuntungan.

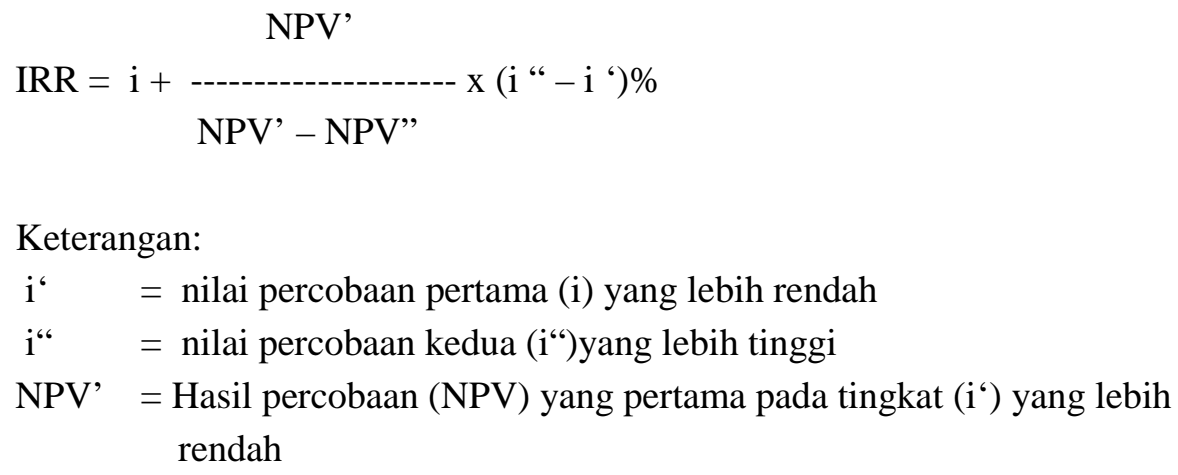


NPV" = Hasil percobaan (NPV) yang kedua pada tingkat $\left(i^{\prime “}\right)$ yang lebih tinggi

Investasi akan layak (diterima), jika IRR > i (tingkat bunga yang berlaku di bank), dan jika IRR $<\mathrm{i}$, akan ditolak karena tidak dapat memberikan manfaat/keuntungan. Kepekaan usaha produksi beras siger terhadap pengaruh yang dapat menyebabkan ketidaklayakapn, digunakan analisis simulasi dengan skenario, yaitu:

- Harga input produksi meningkat

- Harga output produksi menurun, dan

- Harga input produksi meningkat bersamaan dengan penurunan harga output prodpuksi.

\section{HASIL DAN PEMBAHASAN}

Responden penelitian peserta program adalah pelaku pengolahan beras siger di Desa Margomulyo Kecamatan Jati Agung Kabupaten Lampung Selatan. Pemilik bernama Bapak Anggoro. Peserta program saat ini memiliki nilai investasi program mencapai Rp 60,715,000,Beberapa teknologi produksi yang diintroduksi adalah metode proses produksi dan peralatan terbaru mesin grativator, mesin tepung, mensin pencacah, dan mesin pencuci.

Kapasitas produksi pelaku mitra program rata-rata sebanyak $600 \mathrm{~kg}$ beras siger per bulan. Kondisi pemasaran beras siger peserta program selain dipasarkan di wilayah Lampung Selatan, juga telah menjangkau wilayah Kota Bandar Lampung. Terdapat sebagian konsumen yang membawa hasil olahan beras siger ke beberapa kota di Jabodetabek.

Selanjutnya berdasarkan volume penjualan para pelaku pemasaran diketahui bahwa ratarata per bulan mencapai $925 \mathrm{~kg}$. Paling sedikit mereka memasarkan $300 \mathrm{~kg}$ per bulan, dan paling tinggi mencapai $1.500 \mathrm{~kg} /$ bulan. Dengan harga rata-rata sebesar Rp 9.600,-/kg. Sementara harga beli dari produsen rata-rata $\mathrm{Rp} 8.500,-/ \mathrm{kg}$. Rata-rata pedagang mengeluarkan biaya pemasaran mencapai Rp 281.250/bulan.

Struktur biaya dan penerimaan peserta program dapat dilihat pada Tabel 1. Pada Tabel 1 dapat dilihat bahwa komponen biaya peserta program meliputi: biaya investasi, biaya penyusutan, dan biaya variabel (ubi kayu, tenaga kerja, dan listrik)

Tabel 1. Struktur biaya dan penerimaan peserta program

\begin{tabular}{ll}
\hline Komponen Biaya & $(\mathrm{Rp})$ \\
\hline Biaya Investasi & $60,715,000$ \\
Biaya penyusutan/th & $12,218,333$ \\
Biaya Variabel (bulan) & \\
Ubikayu (Kg) & 2,610 \\
Harga (Rp/kg) & 1,000 \\
TK Produksi (HOK) & 11 \\
Harga (Rp/HOK) & 50,000 \\
Listrik (Rp/bulan) & 100,000 \\
Total Biaya Variabel/bl & $3,235,000$ \\
\hline Total Biaya & $63,950,000$ \\
\hline & \\
Penerimaan & Periode produksi per bulan \\
\hline Tiwul (Kg) & 600 \\
Harga (Rp/kg) & 10,000 \\
Penerimaan & $6,000,000$ \\
\hline
\end{tabular}

18 | Volume 3, Nomor 1, Tahun 2019 
Berdasarkan hasil analisis kelayakan finansial peserta program (Tabel 2), pada jangka waktu usaha 5 tahun ternyata usaha pengolahan beras siger tidak feasible karena nilai NPV $<0$, Net $\mathrm{B} / \mathrm{C}<0$, dan IRR <i. Pada situasi tidak terjadi peningkatan kapasitas produksi (produksi jumlahnya konstan) maka usaha ini tidak layak. Berdasarkan kondisi existing peserta program secara finansial belum layak. Usaha beras siger peserta mendapatkan nilai investasi sebagai grant dari pihak ketiga. Besarnya nilai investasi hingga sebesar Rp 60 juta menyebabkan cashflows usaha selama kurun waktu 5 tahun masih belum menghasilkan return yang dapat mengembalikan nilai investasi yang telah dialokasikan.

Berdasarkan penelitian sebelumnya, diketahui bahwa analisis nilai tambah dan kelayakan pengembangan beras siger menunjukkan bahwa setiap pengolahan satu kilogram ubi kayu, akan menghasilkan beras siger sebesar 0,33-0,35 kilogram. Agroindustri beras siger memberikan nilai tambah sebesar Rp1.508,04 per kg-- Rp3.065,38 per kg bahan baku atau 1,68 kali--2,04 kali harga bahan baku. Agroindustri beras siger di Kota Bandar Lampung menghadapi kendala aspek pasar dan teknis penggunaan teknologi sehingga agroindustri masih belum dapat meningkatkan kapasitas produksinya (Novia et al., 2013).

Berdasarkan simulasi yang dilakukan untuk dapat membuat usaha beras siger peserta program menguntungkan dan layak maka perlu dilakukan pendampingan peningkata skala usaha (scale up). Usaha akan layak apabila terjadi peningkatan kapasitas produksi minimal hingga sebesar 20\% dari kondisi existing. Diperlukan waktu 7 tahun untuk dapat menghasilkan nilai NPV lebih dari $0(+)$. NPV positif akan dapat tercapai pada kondisi terjadi peningkatan skala produksi minimal sebesar 20\% (Tabel 3).

Hal ini didasarkan pada fakta bahwa produksi yang berlangsung pada saat penelitian masih belum sesuai dengan kapasitas terpasang peralatan produksi yang optimal. Produksi berlangsung di bawah kapasitas optimal. Hal ini terjadi karena kapasitas pemilik usaha dalam mengalokasikan keperluan biaya produksi (variable) terbatas. Produksi dilakukan dengan pertimbangan utama ketersediaan stok di rumah. Pemilik usaha juga belum memperhitungkan peningkatan produksi dengan kondisi pasar yang diperluas. Produksi mereka terbatas karena pertimbangan penjualan produk yang menunggu pembeli datang. Sementara ini pasar baru mengandalkan pedagang yang dating atau untuk keperluar pameran. Sementara pesanan pembeli sering tidak tentu dalam jumlah dan waktu. Belum ada upaya menembus pasar melalui berbagai jalur yang lebih pasti dan berjangka panjang. Seperti dengan mencari agen atau perwakilan pasar sebagai upaya memperluas pendistribusian. Momen pameran yang biasanya dilakukan oleh pemerintah daerah atau perguruan tinggi seperti ekspo produk pangan lokal yang secara rutin dilakukan di Polinela atau Unila dapat menjadi awal mencari rekanan potensial agen pemasaran produk beras siger. Mencari mitra pasar akan membuat usaha beras siger dapat fokus pada peningkatan skala produksi. Berdasarkan kondisi tersebut, maka pelaku usaha penting fokus pada usaha memperluas pasar baru untuk jaminan peningkatan scale-up produksi usaha beras siger yang dimilikinya. 
DOI: http://dx.doi.org/10.25181/jofsa.v2i2.1415

Journal of Food System and Agribusiness Vol. 3 (1): 15-23 https://www.jurnal.polinela.ac.id/JFA

\section{pISSN 2654-5853}

eISSN 2597-9426

Tabel 1. Analisis finansial peserta program

\begin{tabular}{|c|c|c|c|c|c|c|}
\hline Tahun ke- & 0 & 1 & 2 & 3 & 4 & 5 \\
\hline Pendapatan & $-57,950,000$ & $15,431,667$ & $15,431,667$ & $15,431,667$ & $15,431,667$ & $15,431,667$ \\
\hline df $18 \%$ & 1 & 0.847 & 0.718 & 0.609 & 0.516 & 0.437 \\
\hline B-C/df & $-57,950,000$ & $13,077,684$ & $11,082,783$ & $9,392,189$ & $7,959,482$ & $6,745,324$ \\
\hline C-B & $57,950,000$ & $-15,431,667$ & $-15,431,667$ & $-15,431,667$ & $-15,431,667$ & $-15,431,667$ \\
\hline $\mathrm{C}-\mathrm{B} / \mathrm{df}$ & $57,950,000$ & $-13,077,684$ & $-11,082,783$ & $-9,392,189$ & $-7,959,482$ & $-6,745,324$ \\
\hline Net B/C & -0.167 & & & & & \\
\hline NPV & $(\$ 8,214,016.27)$ & & & & & \\
\hline IRR & $10 \%$ & & & & & \\
\hline
\end{tabular}


Berdasarkan kondisi tersebut di atas, maka dapat disimpulkan bahwa usaha beras siger sangat rentan terhadap perubahan harga input dan output. Meskipun hasil kegiatan transfer teknologi beras siger di Desa Mago Mulyo Kecamatan Jati Agung Lampung Selatan menunjukkan bahwa usaha beras siger telah mampu meningkatkan kapasitas produksi dari 10 kg menjadi 100 kg per minggu; peningkatan keuntungan usaha per minggu dari Rp 20.000 menjadi Rp 350.000; perluasan jangkauan pemasaran dari hanya Desa Margomulyo menjadi Kabupaten Lampung Selatan dan Kota Bandar Lampung (Hidayat, 2016; Surfiana dkk., 2014), namun masih tetap diperlukan upaya peningkatan skala produksi dan pasar yang lebih tinggi. Penelitian yang sudah dilakukan tersebut di atas masih bersifat pilot project. Belum menggambarkan kondisi agroindustri beras siger/tiwul di sentra-sentra produksi di Propinsi Lampung. Oleh karena itu, studi komparasi kelayakan finansial pada beras siger bagi peserta dan nonpeserta MP3L akan memberikan gambaran (mapping) yang lebih utuh. Berdasarkan pembahasan yang telah dilakukan, beberapa hal yang dapat dirumuskan sebagai dasar rekomendasi kebijakan sebagai berikut:

Pendampingan pasar dan scale up produksi menjadi prasyarat jaminan keberlangsungan usaha beras siger modern yang menguntungkan dan berkelanjutan. Inisiasi membangun jejaring pasar antara produsen beras siger menjadi start point yang perlu dilakukan. Trading center produk pangan lokal dan pameran pembangunan di bawah kendali Dinas Pertanian dan Badan Ketahan Pangan Pemerintah Propinsi/Kab/Kota menjadi lokomotif dalam menyiapkan infrastruktur pasar yang diperlukan. Jejaring pelaku distribusi pangan lokal baik dalam konstalasi pasar ritel modern maupun tradisional menjadi awal jaminan pasar bagi produk beras siger yang dihasilkan oleh IRT produsen. Jejaring pelaku usaha beras siger dalam kesatuan asosiasi produsen beras siger dapat menjadi modal dasar jaminan kualitas dan volume yang memenuhi permintaan pasar.

Upaya peningkatan produksi (scale up) bagi peserta program perlu dilakukan secara terstruktur melalui pendampingan teknologi produksi, manajemen pengadaan input, hingga ketersediaan modal melalui kredit lunak dan tenaga kerja terampil.

Pemangku kebijakan pemerintah daerah dari level desa, kecamatan hingga kabupaten/kota/propinsi penting memiliki kerangka kebijakan penguatan bioindustri desa. Diawali dengan informasi mapping IRT pada wilayahnya, inisiasi kelembagaan IRT, jejaring untuk jaminan pasar, pendampingan teknologi produksi, hingga penguatan akses permodalan bagi IRT perdesaan. Basis informasi mapping sentra bioproduksi perdesaan menjadi dasar penentuan besarnya produksi pangan beras siger yang sangat penting dalam memenuhi kebutuhan pangan masyarakat. Lebih lanjut akan menjamin ketahanan pangan dan menurunkan ketergantungan terhadap pangan beras. IRT sebagai basis bioindustri perdesaan menjadi lokomotif sumber pendapatan baru bagi masyarakat perdesaan. Sumber pendapatan baru berarti serapan tenaga kerja baru, yang juga berarti penurunan pengangguran perdesaan. Roda ekonomi desa akan bergulir dengan tumbuhnya IRT perdesaan. Lebih lanjut akan meningkatkan tingkat pendapatan rumah tangga pertanian perdesaan, meningkatkan daya 
beli, menjamin ketahanan pangan, berdaulat pangan, dan menjadi lebih sejahtera. Ekonomi perdesaan tumbuh, maka ekonomi regional pun akan meningkat.

\section{KESIMPULAN}

Struktur biaya agroindustri beras siger peserta program menunjukkan komponen nilai peralatan produksi yang sangat tinggi. Besarnya nilai investasi peserta program mengakibatkan usaha memerlukan waktu minimal 7 tahun untuk dapat memperoleh return yang menguntungkan. Pada situasi kondisi existing, usaha pengoalah beras siger peserta program akan layak apabila meningkatkan kapasitas produksi sebesar $20 \%$.

\section{DAFTAR PUSTAKA}

Adicandra, R. M., \& Estiasih, T. (2016). Beras Analog dari ubi kelapa putih: Kajian Pustaka. Jurnal Pangan Dan Agroindustri, 4(1), 383-390.

Affandi, I. M. I. (2010). Model Pengembangan Klaster Agroindustri Pangan Skala Usaha Kecil Menengah (UKM) Untuk Mengurangi Kemiskinan Sebesar $10 \%$ Propinsi Lampung, Jurnal Penelitian BPTP Vol. 7, 301-302.

BKP Propinsi Lampung. 2013. Program Model Pengembangan Pangan Pokok Lokal. (MP3L) Propinsi Lampung. Laporan kegiatan. Bandar Lampung.

Hidayat, Beni. 2016. Prospek Pengembangan dan Teknologi Pengolahan Beras Siger. UP Politeknik Negeri Lampung. Bandar Lampung

Caesarina, I., \& Estiasih, T. (2016). Beras Analog dari Garut (Maranta arundinaceae): Kajian Pustaka. Jurnal Pangan Dan Industri, 4(2), 498-504.

Downey and Erricson. 1999. Principles of Agribusiness Management.

Elizabeth, R. (2010). Pengembangan Agroindustri Bahan Pangan untuk Peningkatan Nilai Tambah melalui Transformasi Kelembagaan di Pedesaan. Iptek Tanaman Pangan, 5(1), 102-112.

Indarwanta, D., \& Pujiastuti, E. E. (2011). Kajian Potensi (Study Kelayakan) Pengembangan Agroindustri di Desa Gondangan Kecamatan Jonalan Klaten. Jurnal Administasi Bisnis, 8 (Januari), 1-13.

Indiako, M. I. S. D. V., Ismono, R. H., \& Achdiansyah. (2014). Studi perbandingan pola alokasi lahan, pengeluaran beras dan pola konsumsi pangan antara petani ubi kayu di desa pelaksana dan non pelaksana Progral MP3L di Kabupaten Lampung Selatan. Jurnal Ilmu-Ilmu Agribisnis, 2(4), 331-336.

Novia, W., Wan Abbas Zakaria, \& Lestari, D. A. H. (2013). JIIA, Volume 1 No. 3, Juli 2013. Jurnal Ilmu-Ilmu Agribisnis, 1(3), 210-217. 
Pahlevi, R., Zakaria, W. A., \& Kalsum, U. (2014). Analisis Kelayakan Usaha agroindustri Kopi Luwak di Kecamatan Balik Bukit Kabulapen Lampung Barat. Jurnal Ilmu-Ilmu Agribisnis, 2(1), 48-55.

Prasmatiwi, F. E., \& Suryantini, A. (2011). Kesediaan membayar petani kopi untuk perbaikan lingkungan. Jurnal Pelita Pembangunan. Vol 12. No. 1. 2011

Rangkuti, K., Mardhiyah, A., \& Putr, A. D. (2015). Analisis Nilai Tambah Keripik Singkong pada Kelompok Usaha Keluarga (KUK) Desa Sipare-Pare. Jurnal Agrium, 19(2), 116-121.

Sagala, I. C., Affandi, M. I., \& Ibnu, M. (2013). Kinerja usaha agroindustri kelanting di desa karang anyar kecamatan gedongtataan kabupaten pesawaran. Jurnal Ilmu-Ilmu Agribisnis, 1(Januari), 60-65.

Sari, R. P. (2011). Analisis Nilai Tambah dan Kelayakan Agroindustri Chip Ubi Kayu Sebagai Bahan Baku Pembuat Mocaf di Kab. Trenggalek. Brawijaya. diligib.ub.org

Surfiana, Hidayat, B., \& Akmal, S. (2014). Efektivitas Tansfer Teknologi Pengolhan Beras Sige Terhadap Peningkatan Produktivitas Usaha Beras Tiwul Tradisional. Inovasi Dan Pembangunan, 02(03), 32-45.

Yunus, H. A. R., \& Utami, D. P. (2012). Keragaan Agroindustri Opak Singkong di Desa Jolontoro Kec. Saporan, Kab. Wonosobo. Jurnal Surya Agritama, I (Maret), 59-70. 